\title{
One-year results of maxillary overdentures supported by 2 titanium-zirconium implants - implant survival rates and radiographic outcomes
}

\author{
Zembic, Anja ; Tahmaseb, Ali ; Jung, Ronald E ; Wismeijer, Daniel
}

\begin{abstract}
OBJECTIVE To assess implant survival rates and peri-implant bone loss of 2 titanium-zirconium implants supporting maxillary overdentures at 1 year of loading. MATERIAL AND METHODS Twenty maxillary edentulous patients ( 5 women and 15 men) being dissatisfied with their complete dentures were included. In total, 40 diameter-reduced titanium-zirconium implants were placed in the anterior maxilla. Local guided bone regeneration (GBR) was allowed if the treatment did not compromise implant stability. Following 3 to 5 months of healing, implant-supported overdentures were inserted on two ball anchors. Implants and overdentures were assessed at 1,2, 4, and 8 weeks after implant insertion and 2, 4, and 12 months after insertion of overdentures (baseline). Standardized radiographs were taken at implant loading and 1 year. Implant survival rates and bone loss were the primary outcomes. RESULTS Nineteen patients (1 dropout) with 38 implants were evaluated at a mean follow-up of 1.1 years (range 1.0-1.7 years). One implant failed resulting in an implant survival rate of $97.3 \%$. There was a significant peri-implant bone loss of the implants at 1 year of function (mean, $0.7 \mathrm{~mm}, \mathrm{SD}=$ $1.1 \mathrm{~mm}$; median: $0.48 \mathrm{~mm}$, IQR $=0.56 \mathrm{~mm}$ ). CONCLUSIONS There was a high 1-year implant survival rate for edentulous patients receiving 2 maxillary implants and ball anchors as overdenture support. However, several implants exhibited an increased amount of bone loss of more than $2 \mathrm{~mm}$. Overdentures supported by 2 maxillary implants should thus be used with caution as minimally invasive treatment for specific patients encountering problems with their upper dentures until more long-term data is available.
\end{abstract}

DOI: https://doi.org/10.1111/clr.12863

Posted at the Zurich Open Repository and Archive, University of Zurich

ZORA URL: https://doi.org/10.5167/uzh-126610

Journal Article

Accepted Version

Originally published at:

Zembic, Anja; Tahmaseb, Ali; Jung, Ronald E; Wismeijer, Daniel (2017). One-year results of maxillary overdentures supported by 2 titanium-zirconium implants - implant survival rates and radiographic outcomes. Clinical Oral Implants Research, 28(7):e60-e67.

DOI: https://doi.org/10.1111/clr.12863 


\section{1-year results of maxillary overdentures supported}

by 2 titanium-zirconium implants - implant survival rates and radiographic outcomes.

Anja Zembic ${ }^{\S}$, Ali Tahmaseb", Ronald, E. Jung ${ }^{\circ}$, Daniel Wismeijer ${ }^{\#}$

$\S$ Dr. Med. Dent., PhD student, Department of Oral Implantology and Prosthetic Dentistry, Academic Center for Dentistry Amsterdam (ACTA), Move Research Institute, Amsterdam, The Netherlands

$¥$ Senior lecturer, Clinic of Fixed and Removable Prosthodontics and Dental Material Science, University of Zurich, Zurich, Switzerland

ฯ Associate professor, PhD, Department of Oral Implantology and Prosthetic Dentistry, Academic Center for Dentistry Amsterdam (ACTA), Move Research Institute, Amsterdam, The Netherlands

- Professor, Dr. Med. Dent., PhD, Clinic of Fixed and Removable Prosthodontics and Dental Material Science, University of Zurich, Zurich, Switzerland \# Professor, Dr. Med. Dent., Department of Oral Implantology and Prosthetic Dentistry, Academic Center for Dentistry Amsterdam (ACTA), Move Research Institute, Amsterdam, The Netherlands

Keywords: jaw, edentulous, maxilla, dental implants, survival rate, dental prosthesis, implant-supported, alveolar bone loss, bone resorption, titanium-zirconium, ball anchor

Running head: Maxillary overdentures on 2 implants

Address for correspondence:

Dr. Anja Zembic

Clinic of Fixed and Removable Prosthodontics and Dental Material Science University of Zurich

Plattenstrasse 11

8032 Zurich, Switzerland

Phone: +41446343260

Fax: $\quad+41446344305$

E-mail: anja.zembic@zzm.uzh.ch 


\section{Abstract}

Objective: To assess implant survival rates and peri-implant bone loss of 2 titaniumzirconium implants supporting maxillary overdentures at 1 year of loading.

Material and Methods: Twenty maxillary edentulous patients ( 5 women, 15 men) being dissatisfied with their complete dentures were included. In total, 40 diameterreduced titanium-zirconium implants were placed in the anterior maxilla. Local guided bone regeneration (GBR) was allowed if the treatment did not compromise implant stability. Following 3 to 5 months of healing, implant-supported overdentures were inserted on two ball anchors. Implants and overdentures were assessed at 1, 2, 4, 8 weeks after implant insertion and 2, 4 and 12 months after insertion of overdentures (baseline). Standardized radiographs were taken at implant loading and 1 year. Implant survival rates and bone loss were the primary outcomes.

Results: Nineteen patients (1 drop-out) with thirty-eight implants were evaluated at a mean follow-up of 1.1 years (range $1.0-1.7$ years). One implant failed resulting in an implant survival rate of $97.3 \%$. There was a significant peri-implant bone loss of the implants at 1 year of function (mean, $0.7 \mathrm{~mm}, \mathrm{SD}=1.1 \mathrm{~mm}$; median: $0.48 \mathrm{~mm}$, IQR $=0.56 \mathrm{~mm}$ ).

Conclusions: There was a high 1-year implant survival rate for edentulous patients receiving 2 maxillary implants and ball anchors as overdenture support. However, several implants exhibited an increased amount of bone loss of more than $2 \mathrm{~mm}$. Overdentures supported by 2 maxillary implants should thus be used with caution as minimally invasive treatment for specific patients encountering problems with their upper dentures until more long-term data is available. 


\section{Introduction}

In the past, complete dentures were the only treatment option for edentulous patients. Demographic trends indicate that the number of edentulous patients will be relatively high in future, thus the need for complete dentures might persist (Carlsson \& Omar 2010; Polzer et al. 2010).

Dental implants provided the edentulous patients with new treatment alternatives and several factors, such as patient satisfaction, denture retention, function and quality of life improved significantly (Bouma et al. 1997; Strassburger et al. 2006; Wismeijer et al. 1997; Zembic \& Wismeijer 2013).

Even though the frequency of placing oral implants is increasing, a previous review reported differing and small numbers $(0.3 \%$ - $11 \%)$ of edentulous patients undergoing an implant treatment (Zitzmann et al. 2007). The most common reason for the patients not to choose for implants was found to be anxiety for surgical risks, followed by costs (Ellis et al. 2011; Walton \& MacEntee 2005).

Usually maxillary dentures show less retention problems than mandibular dentures. This is mainly caused by an enhanced vacuum effect through the anatomic shape of the maxilla. Once patients start to complain on their maxillary dentures, the retention is often compromised due to advanced ridge resorption. In these situations, bone augmentation techniques such as guided bone regeneration (GBR) or autogenous bone grafts are often inevitable when considering an implant treatment (Chiapasco et al. 2009). This in turn increases the risk for the patient, the patient's morbidity, the costs and the treatment time (Sennerby \& Roos 1998; Stellingsma et al. 2004). Hence, the aversion towards implants becomes evident.

One possibility to avoid bone-grafting procedures might be the use of narrow diameter implants in the anterior maxilla. Thereby, patient's risks and discomforts are reduced in situations with limited bone quantity. The survival of narrow diameter implants was found to be similar to regular diameter implants (Sohrabi et al. 2012). Despite respectable survival rates, it was advised to use narrow diameter titanium implants with caution due to risk of fracture in clinical use (Allum et al. 2008; Buser \& von Arx 2000). 
A recently introduced diameter-reduced implant out of titanium and zirconium alloy offers superior mechanical strength compared to grade 4 titanium and might help overcome the risk of fracture (Ho et al. 2008). In addition, preclinical and clinical studies reported similar osseointegration of this implant to titanium implants (AlNawas et al. 2012; Barter et al. 2012; Chiapasco et al. 2012; Gottlow et al. 2012; Thoma et al. 2011).

A systematic review addressed the question of how many implants are ideal as overdenture support (Roccuzzo et al. 2012). The authors concluded that no answer could be given with regard to the maxilla on the basis of the current evidence. Former systematic reviews with the same goal advised to place at least 4 to even 6 implants in the maxilla (Gallucci et al. 2009; Klemetti 2008; Sadowsky 2007; Slot et al. 2010). This relatively high number of implants as overdenture support makes the treatment both invasive and costly. More minimal-invasive treatment options should be offered to edentulous patients with denture problems out of the above-mentioned reasons. It remains unclear however, how many implants can be minimally inserted in the edentulous maxilla as overdenture support (Jemt et al. 1996; Klemetti 2008; Kronstrom et al. 2006; Roccuzzo et al. 2012).

The placement of 2 implants in the maxilla, as support for overdentures was a treatment option that did not prevail in the past due to low implant survival rates and pronounced bone loss (Bergendal \& Engquist 1998; Quirynen et al. 1991; Sanna et al. 2009). The implants used in these studies had a machined surface. The implant surface is crucial for implant osseointegration. Hence, rough surface implants replaced machined surface implants due to their superior effect on bone integration (Han et al. 1998; Ivanoff et al. 2001; Rasmusson et al. 2001; Wennerberg \& Albrektsson 2009). Consequently, the survival rates significantly increased for rough surface implants placed in the edentulous maxilla compared to machined surface implants at 1, 3, 5 and 10 years (Lambert et al. 2009).

The new titanium-zirconium implant exhibits the successful highly hydrophilic, sandblasted, large-grit, acid-etched surface. Based on the encouraging clinical results, this implant might allow new treatment possibilities, such as the formerly unestablished but minimal-invasive treatment with 2 implants to support maxillary overdentures (Mericske-Stern et al. 2000). 
The aim of the present prospective clinical study was to assess survival rates and peri-implant bone loss of 2 titanium-zirconium implants supporting maxillary overdentures at 1 year of loading. 


\section{Material and Methods}

\section{Patients and study procedure}

The present study was designed as a prospective clinical cohort study including 20 edentulous patients experiencing problems with their maxillary complete dentures. These patients were part of a previously published study describing the details of the procedures (Zembic \& Wismeijer 2013).

In brief: the study was approved by the local ethical committee (Medisch Ethische Toetsingscommissie van Vrije Universiteit Medisch Centrum). The treatment was performed at the Academic Center for Dentistry Amsterdam (ACTA), the Netherlands. All patients were treated by one clinician.

\section{Implant planning}

Upon adjusting the existing dentures or fabricating new ones, a cone beam computed tomography (CBCT)-scan (NewTom 5G, QR, Verona, Italy) was performed using a scan template (duplicate of the denture with barium sulfate). Implants were planned in the prosthetic canine position preferably (coDiagnostiX, Dental Wings Inc. Montreal, Canada). In case of major insufficiency of bone quantity in this region (primary bone graft inevitable), implants were planned posterior or anterior to the canine. In case of minor insufficiency of bone quantity (dehiscence or fenestration defects) not compromising implant stability, implants were planned in canine area. The automatic parallelization feature of the planning software was used to ensure the most parallel position of the 2 implants in the mesio-distal as well as bucco-lingual plane. When needed, the parallelized implant position was adjusted manually according to the individual bone conditions. The scan template was translated into a template for guided surgery according to the virtual implant planning and using the manufacturer`s device (gonyX ${ }^{\mathrm{TM}}$, Institut Straumann AG, Basel, Switzerland).

\section{Surgery}

The patients received antibiotics as single shot dose 1 hour preoperative (Amoxicilline 3g) (Amoxicillin Sandoz ${ }^{\circledR}$ Pharmaceuticals AG, Rotkreuz, Switzerland). Mouth rinsing was administered 1 day before surgery with a solution of $0.12 \%$ chlorhexidine digluconate (Perio•Aid ${ }^{\circledR}$, Dentaid, Barcelona, Spain). 
In situations with no bone defects according to the virtual planning, soft tissue punches were performed through the sleeves by means of disposable biopsy tissue punches with a standardized diameter of $4 \mathrm{~mm}$ (Integra ${ }^{\mathrm{TM}}$ Miltex $^{\circledR}$, Plainsboro, New Jersey, USA). Subsequently, guided drilling was performed (Straumann Guided ${ }^{\circledR}$ Surgery kit, Institut Straumann AG, Basel, Switzerland). Two diameter-reduced implants (Roxolid ${ }^{\circledR}$ Tissue Level, 3.3mm diameter, Regular Neck, Institut Straumann AG, Basel, Switzerland) were placed through the guided implant mount. Implants with a standard shoulder height of $2.8 \mathrm{~mm}$ or with a reduced shoulder height of $1.8 \mathrm{~mm}$ were placed, dependent on the mucosa thickness. The rough-smooth border of the implants was placed either at bone crest or slightly subcrestal by means of a guided vertical reference. Closure screws or healing abutments were inserted dependent on the mucosa thickness and the implants were exposed to transmucosal healing for 2 months.

In situations with expected bone defects, a flap was raised and guided bone regeneration (GBR) was applied simultaneously with the placement of two diameterreduced implants. Implants were placed in the same way as mentioned above. Autogenous bone chips gained from the surrounding bone were applied on the exposed implant threads, followed by a xenograft material (Bio-Oss ${ }^{\circledR}$, Geistlich Pharma AG, Wolhusen, Switzerland). A resorbable collagen membrane was used to cover the graft (Bio-Gide ${ }^{\circledR}$, Geistlich Pharma AG, Wolhusen, Switzerland). Closure screws were inserted into the implants. A periosteal releasing incision was performed if needed and the flap was closed tension-free with non-resorbable PTFE monofilament sutures (Cytoplast ${ }^{\mathrm{TM}}$, Osteogenics Biomedical, Inc., Lubbock, USA). Submucosal implant healing was allowed for 4 months.

The patients were instructed postoperatively to rinse twice daily for 2 weeks with a solution of $0.12 \%$ chlorhexidine digluconate (Perio $\bullet \mathrm{Aid}^{\circledR}{ }^{\circledR}$, Dentaid, Barcelona, Spain). Analgesics (Brufen ${ }^{\circledR}$ Bruis 600 mg, Abbott, Illinois, USA) were prescribed according to patient's individual requirements. All patients were instructed not to wear the maxillary dentures for 1 week after implant surgery. One week post-operatively, sutures were removed and the dentures were thoroughly grinded out in the implant area. Soft relining was done occasionally (Soft-Liner, GC corporation, Tokyo, Japan). If the implant healing was submerged, abutment connection was performed after 4 months and healing abutments were inserted. One week thereafter, implant impressions were made. In case of transmucosal healing, implant impressions were 
performed 2 months after implant insertion. Radiographs of the implants were performed using the long-cone parallel technique for control of the correct fit oft he impression posts (Updegrave 1951).

\section{Prosthodontic procedure}

Definitive overdentures were inserted 3 and 5 months after implant placement. Thus, all implants were loaded conventionally (Esposito et al. 2007).

At the day of overdenture insertion, 2 titanium retentive anchors with a standardized height of $3.4 \mathrm{~mm}$ (Retentive anchor abutment, Institut Straumann AG) were screwed into the implants with a defined torque of $35 \mathrm{Ncm}$. The corresponding matrices (Titanium matrix for retentive anchor, Institut Straumann AG, Switzerland) were incorporated into the overdentures by the dental technician. The overdentures were designed with a metal framework and conventional full palatal coverage. The patients wore these overdentures for 2 months. Subsequently, the overdentures were sent to the lab for reduction of the palatal coverage and the patients wore the modified overdentures for another 2 months. This overdenture modification was part of another research project (Zembic et al. 2013). The patients could thereafter choose which overdenture type they preferred, either with closed or open palatal design. The occlusion of the overdentures was controlled and corrected to be balanced and without anterior contacts (Horn 1987). Specific instructions were given on overdenture handling and oral hygiene. The patients were enrolled in an individual dental hygiene program every 6-12 months, either at the University of Amsterdam or at private practices.

\section{Clinical evaluation and outcome measures}

The patients were followed-up 1, 2, 4, 8 weeks after implant insertion and 2, 4 and 12 months after insertion of overdentures (baseline). At all visits, a clinical control of mucosa, implants and overdentures took place and adverse events were noted. Radiographic assessments were performed at implant loading and 1 year of followup.

The main outcome measures were:

- Implant survival rate

- Peri-implant marginal bone loss 
Secondary outcomes were:

- Peri-implant mucosa

- Overdentures

An implant was considered as "surviving implant", if it remained inserted during the observation period (Albrektsson et al. 1986).

Standardized digital radiographs were performed perpendicular to the implant axis with the long-cone technique (Updegrave 1951). For this purpose, lab-made individual implant-supported $\mathrm{x}$-ray holders were used which were made on the cast after implant impression (Figure 1). Two examiners (BH, $\mathrm{AZ}$ ) evaluated mesial and distal bone levels at implant loading and 1 year using a software program (Image $\mathrm{J}$; National Institutes of Health, Bethesda, MD, USA). The distance from the first boneto-implant-contact to the implant shoulder as reference point was measured in 0.1 $\mathrm{mm}$ increments (Figure 2a,b). The known distance between implant threads was used for calibration $(1.25 \mathrm{~mm})$. In case of measurement discrepancies of more than $0.5 \mathrm{~mm}$, the radiographs were re-examined and discussed until a consensus was found. The Cohen's Kappa- coefficient was calculated to assess the agreement between the two examinators. Mesial and distal bone loss measurements were averaged per implant. Then, the average of both implants per patient was used for the analysis of bone loss between baseline and 1 year, i.e. the unit of the analysis was the patient.

\section{Statistical Analysis}

Descriptive statistics was applied calculating means, medians, standard deviations and interquartile ranges of bone loss. Bone loss from baseline to 12 months was statistically assessed using the Wilcoxon signed rank test. The level of significance was set at $5 \%$. 


\section{Results}

\section{Patients and implants}

In total, forty implants in twenty maxillary edentulous patients (5 women, 15 men) were included in the present study. The mean age of the patients was 61 years (range 45-84 years) at the time of surgery.

Six patients (6 men) were smokers, whereas 14 patients (5 women, 9 men) were non-smokers. One patient (smoker) withdrew from the study due to personal reasons. Consequently, thirty-eight titanium-zirconium implants in nineteen patients were examined at a mean follow-up of 1.1 years (range $1.0-1.7$ years).

Primary implant stability was achieved with all implants.

The location and distribution of implant type and length is illustrated in Table 1. The majority of implants $(n=34)$ were placed in pristine bone with a flapless approach. An open flap procedure and simultaneous minor bone augmentation was performed for 4 implants.

Fifteen patients preferred an overdenture with reduced palatal coverage, whereas four patients chose for a full palatal coverage.

In the opposing jaw, fifteen patients had mandibular implant-supported overdentures, 3 patients had complete mandibular dentures and 1 patient had three remaining natural teeth and a partial denture.

\section{Implant survival}

The implant survival rate at 1 year amounted to $97.3 \%$.

One implant failed out of the evaluated thirty-eight implants due to loss of osseointegration 2 weeks prior to the 1-year follow-up visit. This implant was placed flapless without GBR. The patient was occasional pipe smoker and chose for an overdenture with reduced palatal coverage. There was abnormal tooth wear visible 7 months following overdenture insertion indicating parafunctions.

In the lower jaw the patient was wearing an overdenture on 2 implants and a bar. The patient reported pain when removing the overdenture and was scheduled for a control. The implant was mobile and could be removed manually. The socket was cleaned carefully and all granulation tissue was removed. A new implant was successfully re-inserted at the same location (region 23) after 2 months of healing with minor local GBR. 


\section{Marginal bone loss}

The inter-rater agreement (Kappa) of the two examiners was $\mathrm{k}=0.82$, which corresponds to a very good agreement.

The bone loss is illustrated in Tables 2-5 and Figures 3 a-d, 4 a-d.

There was significant bone loss at 1 year $(\mathrm{p}<0.01,95 \% \mathrm{Cl}: 0.28-0.95 \mathrm{~mm}$, Wilcoxon signed rank test). Overall, when averaging over implants and patients, the mean bone loss amounted to $0.7 \mathrm{~mm}( \pm 1.1)$ and the median bone loss was $0.48 \mathrm{~mm}$ (IQR: $0.56 \mathrm{~mm})$.

At the 12-month follow-up, bone loss up till $2 \mathrm{~mm}$ was observed around twenty-three implants (62\%). Bone loss of 2-3 mm was found around 1 implant (3\%), whereas bone loss of more than $3 \mathrm{~mm}$ was identified around 2 implants (5\%). In eleven implants (30\%) either no bone loss or slight bone gain was evident.

The descriptive bone loss of implants split to the variables GBR, smoking and overdentures with/without palatal coverage is presented in Tables 3-5.

\section{Peri-implant mucosa}

\section{Until 2 months of loading:}

- Mucosa overgrowth around 7 implants of 5 patients

- Pain spot in 1 patient

\section{At 2 months of loading:}

- Mucosa overgrowth around 3 implants of 2 patients

\section{At 4 months of loading:}

- No events

\section{At 1 year of loading:}

- Mucosa overgrowth around 1 implant of 1 patient

- Recession around 1 implant of 1 patient

In all patients with mucosa overgrowth mucosa excisions were performed. In total, 13 soft tissue events occurred at 1 year. Two clinical case examples are presented in Figure 5a,b.

\section{Overdentures}




\section{Until 2 months of loading:}

- 1 overdenture tooth 23 fracture (lab repair)

- 1 rebasing (direct)

\section{At 2 months of loading:}

- 1 fracture of the buccal shield in region of 11-14 (lab repair)

- 1 rebasing (direct)

- 1 phonetic problem, palatal coverage thinned out and directly rebased

- 1 patient reports pain when inserting the overdenture in the morning (this patient suffered from mucosa overgrowth)

\section{At 4 months of loading:}

- 1 patient reports pain when inserting the overdenture in the morning (same patient as at 2 months)

\section{Between 4 months and 1 year:}

- 2 partial overdenture tooth fractures (teeth 11, 12) in 2 patients (direct repair)

- 1 partial direct rebasing

- 1 direct rebasing, 1 indirect rebasing in one and the same patient

- pronounced tooth abrasion and fractured incisors in 1 patient (no repair needed, just polished; this patient lost 1 implant)

\section{At 1 year of loading:}

- 1 minor overdenture tooth fracture 22 (no repair needed, just polished)

Overall, there were 4 minor fractures which could be resolved chairside by either polishing or composite build-ups and 2 major fractures, which were sent to the dental technician for repair. At 1 year, 5 overdentures were rebased directly chairside. One overdenture was sent to the lab for an indirect rebasing. 


\section{Discussion}

The results of the present study demonstrated a high implant survival rate for 2 maxillary implants supporting overdentures at 1 year of function. There was significant peri-implant bone loss from implant loading to the 1-year follow-up.

\section{Implant survival rate}

A lower implant survival rate (82.1\%) than in the present study was reported in a study on 2 narrow diameter implants placed in the canine area of fourteen patients (Weng \& Richter 2007). The mean observation period was 25.6 months which is longer than in the present study. Likewise as in the present study, implants were loaded with a conventional approach, i.e. 2 and more months following implant placement (Esposito et al. 2007). Conventional implant loading in the edentulous jaw supporting overdentures had a positive impact on implant survival with less implant failures compared to shorter healing times (Kern et al. 2016; Schimmel et al. 2014). Still, there was a high number of failures in the named study even after 7 months of healing before loading.

The overdentures were of similar design as in the present study with a metal framework and open palatal design but supported by 2 telescopic abutments (Weng \& Richter 2007). Telescopic abutments are more rigid than ball anchors which might have affected the load transfer to implants and accordingly the implant survival rates in a negative way. On the other hand, there were no differences for the survival rates of 4 maxillary implants supporting overdentures with either telescopic crowns, bar or locator attachments in a prospective study at 3 years (Zou et al. 2013). Unfortunately, there was no random allocation of the 3 attachment systems. One might speculate that the attachment system is not likely to influence implant survival rates when 4 implants are placed in the maxilla, but might have an effect when less than 4 implants are inserted. Furthermore, this might apply primarily for rigid telescopic attachments compared to ball attachments with a higher degree of freedom. In another study, the patients were randomly assigned to splinted maxillary implants by means of a bar and to un-splinted implants by means of ball attachments (Bergendal \& Engquist 1998). Sixteen patients received less than 4 implants in the maxilla. No significant differences were found for the survival of splinted vs. unsplinted implants at 5 years (Bergendal \& Engquist 1998). Thus, bar and ball 
attachments seem not to have an impact on implant survival rates, even when less than 4 implants are placed in the maxilla.

Another study also presented an inferior 1-year survival rate of $84.6 \%$ for 3 narrow diameter implants supporting maxillary overdentures (Payne et al. 2004). In contrast to the present study, all implants were placed in combination with ridge-expansion and ridge-splitting, a technique not well approved with regard to implant survival rates. On the other hand, only minor GBR was applied in the 4/38 study implants for coverage of dehiscence or fenestration defects. The GBR technique is well documented in implant dentistry. A systematic review reports high survival rates of $95.7 \%$ (range $84.7 \%$ to $100 \%$ ) at $1-10$ years for implants placed with GBR to treat peri-implant dehiscence and fenestration defects in the maxilla (Chiapasco \& Zaniboni 2009). Thus, it is unlikely that the applied minor GBR had an influence on the survival rate in the present study. It does not surprise hence that the failed implant was not in conjunction with GBR.

The favorable implant survival rates in the present study should be interpreted with caution though due to the short observation period. The implants are to be monitored over a longer period before this treatment option can be recommended on a large scale. Besides, less than 4 maxillary implants as overdenture support showed a 3 times increased estimated risk for implant loss compared to 4 maxillary implants $(2.3$ vs. 7.2, p<0.0001) according to a recent systematic review (Kern et al. 2016). On the other hand it is well known that most implant failures are early failures and occur during initial implant healing, whereas less than $50 \%$ of the failures usually correspond to late failures, which happen when the established osseointegration cannot be sustained (Schley \& Wolfart 2011).

\section{Peri-implant bone loss}

The majority of implants (62\%) in the present study showed a maximum bone loss of $2 \mathrm{~mm}$, which is within the range of previously reported implant success criteria (Albrektsson et al. 1986). Three implants in 2 patients ( $8 \%$ of the implants) lost more than $2 \mathrm{~mm}$ of bone. Several reasons might have contributed to this finding. These implants were placed flapless without GBR. Still, 1 of these 2 patients had poor initial bone conditions. Bone quality and quantity are often compromised in the maxilla (Chan et al. 1998). Both patients had overdentures with reduced palatal coverage, which might have subjected the implants to biomechanical stress (Rodriguez et al. 
2000). The other patient had good initial bone conditions but was smoking 1-package cigarettes per day. Smoking is well known to have a harmful effect and cause more peri-implant bone loss in the maxilla (Clementini et al. 2014; Vervaeke et al. 2013). A current systematic review found smoking to increase the annual rate of bone loss by $0.16 \mathrm{~mm} /$ year (Clementini et al. 2014). Furthermore, this patient showed abnormal tooth wear at 7 months indicating parafunctions.

The same implant type and material was used for rehabilitation of the atrophic maxilla in a retrospective study (Cordaro et al. 2013). Ten patients received 4 implants and locator abutments as overdenture support. There was less mean bone loss $(0.55 \pm 0.5 \mathrm{~mm})$ at a mean observation period of 13.5 months than reported in the present study. Retrospective studies tend to be less critical than prospective ones and often show more favorable outcomes. In addition, the attachment system might have contributed to minor bone loss. An advantage of locator abutments as against to ball anchors with pre-defined height is the wide range of available locator heights. This enables an optimal choice of the retentive anchor according to the individual mucosa thickness. Thereby, the peri-implant soft tissue support is facilitated and mucosal problems can be prevented. Thirty percent of the implants showed mucosa overgrowth in the present study, inducing a peri-implant mucositis. This might explain the bone loss. The use of e.g. locators might have been more advantageous, but due to no available evidence on locators in the edentulous maxilla by the time of study beginning, it was chosen to use the well proven ball anchors.

Interestingly, some bone loss is evident on the baseline x-rays, i.e. from implant insertion to implant loading. A similar observation with a mean bone loss of $1.35 \pm 01$ $\mathrm{mm}$ was found between implant surgery and 12 weeks in a prospective study on 3 maxillary implants supporting overdentures (Ma et al. 2015). In the edentulous upper jaw positioning of the $\mathrm{x}$-ray is difficult to achieve in a reproducible angle due to the palatal anatomy. To be able to compare bone levels in a standardized way, individual stents were fabricated on the casts after implant impression. Thus, baseline radiographs were taken at prosthesis insertion in the present study, i.e. implant loading, which is in agreement with the consensus of the Sixth European Workshop on Periodontology (2008) (Heitz-Mayfield 2008). Considering the questionable benefit of baseline $x$-rays at the day of implant insertion, it nevertheless would have been interesting to see how much bone was lost during the healing period. 
The healing pattern of most implants $(88 \%)$ was transmucosal. Several studies found no significant difference in bone loss when transmucosal implant healing was compared to submerged implant healing (Astrand et al. 2002; Cecchinato et al. 2004; Ericsson et al. 1997; Hammerle et al. 2012). Those studies base on partially edentulous patients. Transmucosal healing in the edentulous jaw might in turn expose implants to risks such as premature loading through the denture and mucosa overgrowth.

Taking into account the growing elderly population, there is a need of clinical trials to validate the use of freestanding implants supporting maxillary overdentures (Gallucci et al. 2009). Thereby, priority should be given to straightforward, efficient and minimal invasive treatment procedures that come along with less surgical risks for the patients (Chiapasco et al. 2009). This might be achieved by the placement of less than 4 implants in the maxilla as overdentures support. To substantiate the treatment concept of only 2 maxillary implants, the present results have to be monitored over a longer period of time and corroborated by more clinical data. 


\section{Conclusions}

The high short-term implant survival rates suggest that maxillary overdentures supported by 2 implants might be a minimal invasive treatment alternative worth to be considered in specific patients encountering problems with conventional maxillary dentures. The increased bone loss has to be considered though and might have a negative effect on the clinical long-term outcome of this treatment option. Thus, monitoring over a longer period than 1 year and more clinical studies are needed to prove this treatment option to be successful.

\section{Acknowledgements}

The present study was funded by the Academic Center for Dentistry Amsterdam (ACTA), The Netherlands. Institut Straumann AG, Basel, Switzerland, provided the material for the study free of charge. The authors would like to thank Sirarpi Pogosian, Academic Center for Dentistry Amsterdam (ACTA), The Netherlands, for the help with organizing the data. Further thanks go to PhD Bassam Hassan and the department of radiology, Academic Center for Dentistry Amsterdam (ACTA), The Netherlands for the CBCT-scans and evaluation of the radiographic data. Gratitude goes also to Dr. Walter Bürgin, School of Dental Medicine, University of Bern, Switzerland, for the statistics. The authors would furthermore like to thank Martin Bub, master dental technician and his team from technical laboratory Zutphen (Tandtechnisch Laboratorium Zutphen, Zutphen, The Netherlands) for fabrication of overdentures and radiographic holders. Finally, thanks go to Gisela Müller, Center of Dental Medicine, University of Zurich, Switzerland for the support with the editing of the manuscript. 


\section{References}

Al-Nawas, B., Bragger, U., Meijer, H. J., Naert, I., Persson, R., Perucchi, A., Quirynen, M., Raghoebar, G. M., Reichert, T. E., Romeo, E., Santing, H. J., Schimmel, M., Storelli, S., ten Bruggenkate, C., Vandekerckhove, B., Wagner, W., Wismeijer, D. \& Muller, F. (2012) A double-blind randomized controlled trial (rct) of titanium-13zirconium versus titanium grade iv small-diameter bone level implants in edentulous mandibles--results from a 1-year observation period. Clinical Implant Dentistry and Related Research 14: 896-904.

Albrektsson, T., Zarb, G., Worthington, P. \& Eriksson, A. R. (1986) The long-term efficacy of currently used dental implants: A review and proposed criteria of success. International Journal of Oral and Maxillofacial Implants 1: 11-25.

Allum, S. R., Tomlinson, R. A. \& Joshi, R. (2008) The impact of loads on standard diameter, small diameter and mini implants: A comparative laboratory study. Clinical Oral Implants Research 19: 553-559.

Astrand, P., Engquist, B., Anzen, B., Bergendal, T., Hallman, M., Karlsson, U., Kvint, S., Lysell, L. \& Rundcrantz, T. (2002) Nonsubmerged and submerged implants in the treatment of the partially edentulous maxilla. Clinical Implant Dentistry and Related Research 4: 115-127.

Barter, S., Stone, P. \& Bragger, U. (2012) A pilot study to evaluate the success and survival rate of titanium-zirconium implants in partially edentulous patients: Results after 24 months of follow-up. Clinical Oral Implants Research 23: 873-881.

Bergendal, T. \& Engquist, B. (1998) Implant-supported overdentures: A longitudinal prospective study. International Journal of Oral and Maxillofacial Implants 13: 253262.

Bouma, J., Boerrigter, L. M., Van Oort, R. P., van Sonderen, E. \& Boering, G. (1997) Psychosocial effects of implant-retained overdentures. International Journal of Oral and Maxillofacial Implants 12: 515-522.

Buser, D. \& von Arx, T. (2000) Surgical procedures in partially edentulous patients with iti implants. Clinical Oral Implants Research 11 Suppl 1: 83-100.

Carlsson, G. E. \& Omar, R. (2010) The future of complete dentures in oral rehabilitation. A critical review. Journal of Oral Rehabilitation 37: 143-156.

Cecchinato, D., Olsson, C. \& Lindhe, J. (2004) Submerged or non-submerged healing of endosseous implants to be used in the rehabilitation of partially dentate patients. Journal of Clinical Periodontology 31: 299-308.

Chan, M. F., Narhi, T. O., de Baat, C. \& Kalk, W. (1998) Treatment of the atrophic edentulous maxilla with implant-supported overdentures: A review of the literature. International Journal of Prosthodontics 11: 7-15.

Chiapasco, M., Casentini, P. \& Zaniboni, M. (2009) Bone augmentation procedures in implant dentistry. International Journal of Oral and Maxillofacial Implants 24 Suppl: 237-259.

Chiapasco, M., Casentini, P., Zaniboni, M., Corsi, E. \& Anello, T. (2012) Titaniumzirconium alloy narrow-diameter implants (straumann roxolid((r))) for the rehabilitation of horizontally deficient edentulous ridges: Prospective study on 18 consecutive patients. Clinical Oral Implants Research 23: 1136-1141.

Chiapasco, M. \& Zaniboni, M. (2009) Clinical outcomes of gbr procedures to correct peri-implant dehiscences and fenestrations: A systematic review. Clinical Oral Implants Research 20 Suppl 4: 113-123.

Clementini, M., Rossetti, P. H., Penarrocha, D., Micarelli, C., Bonachela, W. C. \& Canullo, L. (2014) Systemic risk factors for peri-implant bone loss: A systematic 
review and meta-analysis. International Journal of Oral and Maxillofacial Surgery 43: 323-334.

Cordaro, L., Torsello, F., Mirisola di Torresanto, V. \& Baricevic, M. (2013)

Rehabilitation of an edentulous atrophic maxilla with four unsplinted narrow diameter titanium-zirconium implants supporting an overdenture. Quintessence International 44: 37-43.

Ellis, J. S., Levine, A., Bedos, C., Mojon, P., Rosberger, Z., Feine, J. \& Thomason, J. M. (2011) Refusal of implant supported mandibular overdentures by elderly patients. Gerodontology 28: 62-68.

Ericsson, I., Randow, K., Nilner, K. \& Petersson, A. (1997) Some clinical and radiographical features of submerged and non-submerged titanium implants. A 5year follow-up study. Clinical Oral Implants Research 8: 422-426.

Esposito, M., Grusovin, M. G., Willings, M., Coulthard, P. \& Worthington, H. V. (2007) The effectiveness of immediate, early, and conventional loading of dental implants: $A$ cochrane systematic review of randomized controlled clinical trials. International Journal of Oral and Maxillofacial Implants 22: 893-904.

Gallucci, G. O., Morton, D. \& Weber, H. P. (2009) Loading protocols for dental implants in edentulous patients. International Journal of Oral and Maxillofacial Implants 24 Suppl: 132-146.

Gottlow, J., Dard, M., Kjellson, F., Obrecht, M. \& Sennerby, L. (2012) Evaluation of a new titanium-zirconium dental implant: A biomechanical and histological comparative study in the mini pig. Clinical Implant Dentistry and Related Research 14: 538-545. Hammerle, C. H., Jung, R. E., Sanz, M., Chen, S., Martin, W. C. \& Jackowski, J. (2012) Submerged and transmucosal healing yield the same clinical outcomes with two-piece implants in the anterior maxilla and mandible: Interim 1-year results of a randomized, controlled clinical trial. Clinical Oral Implants Research 23: 211-219. Han, C. H., Johansson, C. B., Wennerberg, A. \& Albrektsson, T. (1998) Quantitative and qualitative investigations of surface enlarged titanium and titanium alloy implants. Clinical Oral Implants Research 9: 1-10.

Heitz-Mayfield, L. J. (2008) Peri-implant diseases: Diagnosis and risk indicators. Journal of Clinical Periodontology 35: 292-304.

Ho, W. F., Chen, W. K., Wu, S. C. \& Hsu, H. C. (2008) Structure, mechanical properties, and grindability of dental ti-zr alloys. J Mater Sci Mater Med 19: 31793186.

Horn, R., Stuck, J. (1987) Die okklusion in der totalprothetik. In: Horn, r. \& stuck, j., eds. Zahnaufstellung in der totalprothetik. Ein leitfaden für zahnarzt und zahntechniker. 2. Auflage. Quintessenz, berlin.: 13-17. Ivanoff, C. J., Hallgren, C., Widmark, G., Sennerby, L. \& Wennerberg, A. (2001) Histologic evaluation of the bone integration of tio(2) blasted and turned titanium microimplants in humans. Clinical Oral Implants Research 12: 128-134.

Jemt, T., Chai, J., Harnett, J., Heath, M. R., Hutton, J. E., Johns, R. B., McKenna, S., McNamara, D. C., van Steenberghe, D., Taylor, R., Watson, R. M. \& Herrmann, I. (1996) A 5-year prospective multicenter follow-up report on overdentures supported by osseointegrated implants. International Journal of Oral and Maxillofacial Implants 11: 291-298.

Kern, J. S., Kern, T., Wolfart, S. \& Heussen, N. (2016) A systematic review and meta-analysis of removable and fixed implant-supported prostheses in edentulous jaws: Post-loading implant loss. Clinical Oral Implants Research 27: 174-195. Klemetti, E. (2008) Is there a certain number of implants needed to retain an overdenture? Journal of Oral Rehabilitation 35 Suppl 1: 80-84. 
Kronstrom, M., Widbom, C. \& Soderfeldt, B. (2006) Patient evaluation after treatment with maxillary implant-supported overdentures. Clinical Implant Dentistry and Related Research 8: 39-43.

Lambert, F. E., Weber, H. P., Susarla, S. M., Belser, U. C. \& Gallucci, G. O. (2009) Descriptive analysis of implant and prosthodontic survival rates with fixed implantsupported rehabilitations in the edentulous maxilla. Journal of Periodontology 80: 1220-1230.

Ma, S., Tawse-Smith, A., De Silva, R. K., Atieh, M. A., Alsabeeha, N. H. \& Payne, A. G. (2015) Maxillary three-implant overdentures opposing mandibular two-implant overdentures: 10-year surgical outcomes of a randomized controlled trial. Clinical Implant Dentistry and Related Research.

Mericske-Stern, R. D., Taylor, T. D. \& Belser, U. (2000) Management of the edentulous patient. Clinical Oral Implants Research 11 Suppl 1: 108-125.

Payne, A. G., Tawse-Smith, A., Thomson, W. M., Duncan, W. D. \& Kumara, R. (2004) One-stage surgery and early loading of three implants for maxillary overdentures: A 1-year report. Clinical Implant Dentistry and Related Research 6: 6174.

Polzer, I., Schimmel, M., Muller, F. \& Biffar, R. (2010) Edentulism as part of the general health problems of elderly adults. International Dental Journal 60: 143-155. Quirynen, M., Naert, I., van Steenberghe, D., Teerlinck, J., Dekeyser, C. \& Theuniers, G. (1991) Periodontal aspects of osseointegrated fixtures supporting an overdenture. A 4-year retrospective study. Journal of Clinical Periodontology 18: 719-728.

Rasmusson, L., Kahnberg, K. E. \& Tan, A. (2001) Effects of implant design and surface on bone regeneration and implant stability: An experimental study in the dog mandible. Clinical Implant Dentistry and Related Research 3: 2-8.

Roccuzzo, M., Bonino, F., Gaudioso, L., Zwahlen, M. \& Meijer, H. J. (2012) What is the optimal number of implants for removable reconstructions? A systematic review on implant-supported overdentures. Clinical Oral Implants Research 23 Suppl 6: 229-237.

Rodriguez, A. M., Orenstein, I. H., Morris, H. F. \& Ochi, S. (2000) Survival of various implant-supported prosthesis designs following 36 months of clinical function. Annals of Periodontology 5: 101-108.

Sadowsky, S. J. (2007) Treatment considerations for maxillary implant overdentures: A systematic review. Journal of Prosthetic Dentistry 97: 340-348.

Sanna, A., Nuytens, P., Naert, I. \& Quirynen, M. (2009) Successful outcome of splinted implants supporting a 'planned' maxillary overdenture: A retrospective evaluation and comparison with fixed full dental prostheses. Clinical Oral Implants Research 20: 406-413.

Schimmel, M., Srinivasan, M., Herrmann, F. R. \& Muller, F. (2014) Loading protocols for implant-supported overdentures in the edentulous jaw: A systematic review and meta-analysis. International Journal of Oral and Maxillofacial Implants 29 Suppl: 271-286.

Schley, J. S. \& Wolfart, S. (2011) Which prosthetic treatment concepts present a reliable evidence-based option for the edentulous maxilla related to number and position of dental implants? European Journal of Oral Implantology 4 Suppl: S31-47. Sennerby, L. \& Roos, J. (1998) Surgical determinants of clinical success of osseointegrated oral implants: A review of the literature. International Journal of Prosthodontics 11: 408-420.

Slot, W., Raghoebar, G. M., Vissink, A., Huddleston Slater, J. J. \& Meijer, H. J. (2010) A systematic review of implant-supported maxillary overdentures after a mean observation period of at least 1 year. Journal of Clinical Periodontology 37: 98-110. 
Sohrabi, K., Mushantat, A., Esfandiari, S. \& Feine, J. (2012) How successful are small-diameter implants? A literature review. Clinical Oral Implants Research 23: 515-525.

Stellingsma, K., Raghoebar, G. M., Meijer, H. J. \& Stegenga, B. (2004) The extremely resorbed mandible: A comparative prospective study of 2-year results with 3 treatment strategies. International Journal of Oral and Maxillofacial Implants 19: 563-577.

Strassburger, C., Kerschbaum, T. \& Heydecke, G. (2006) Influence of implant and conventional prostheses on satisfaction and quality of life: A literature review. Part 2: Qualitative analysis and evaluation of the studies. International Journal of Prosthodontics 19: 339-348.

Thoma, D. S., Jones, A. A., Dard, M., Grize, L., Obrecht, M. \& Cochran, D. L. (2011) Tissue integration of a new titanium-zirconium dental implant: A comparative histologic and radiographic study in the canine. Journal of Periodontology 82: 14531461.

Updegrave, W. J. (1951) The paralleling extension-cone technique in intraoral dental radiography. Oral Surgery, Oral Medicine, Oral Pathology 4: 1250-1261.

Vervaeke, S., Collaert, B., Cosyn, J., Deschepper, E. \& De Bruyn, H. (2013) A multifactorial analysis to identify predictors of implant failure and peri-implant bone loss. Clinical Implant Dentistry and Related Research.

Walton, J. N. \& MacEntee, M. I. (2005) Choosing or refusing oral implants: A prospective study of edentulous volunteers for a clinical trial. International Journal of Prosthodontics 18: 483-488.

Weng, D. \& Richter, E. J. (2007) Maxillary removable prostheses retained by telescopic crowns on two implants or two canines. International Journal of Periodontics and Restorative Dentistry 27: 35-41.

Wennerberg, A. \& Albrektsson, T. (2009) Effects of titanium surface topography on bone integration: A systematic review. Clinical Oral Implants Research 20 Suppl 4: 172-184.

Wismeijer, D., Van Waas, M. A., Vermeeren, J. I., Mulder, J. \& Kalk, W. (1997) Patient satisfaction with implant-supported mandibular overdentures. A comparison of three treatment strategies with iti-dental implants. International Journal of Oral and Maxillofacial Surgery 26: 263-267.

Zembic, A., Tahmaseb, A. \& Wismeijer, D. (2013) Within-subject comparison of maxillary implant-supported overdentures with and without palatal coverage. Clinical Implant Dentistry and Related Research.

Zembic, A. \& Wismeijer, D. (2013) Patient-reported outcomes of maxillary implantsupported overdentures compared with conventional dentures. Clinical Oral Implants Research.

Zitzmann, N. U., Hagmann, E. \& Weiger, R. (2007) What is the prevalence of various types of prosthetic dental restorations in europe? Clinical Oral Implants Research 18 Suppl 3: 20-33.

Zou, D., Wu, Y., Huang, W., Wang, F., Wang, S., Zhang, Z. \& Zhang, Z. (2013) A 3year prospective clinical study of telescopic crown, bar, and locator attachments for removable four implant-supported maxillary overdentures. International Journal of Prosthodontics 26: 566-573. 
Figure 1. Individualized lab-made radiographic holder attached to the ball anchor.

Figure 2a. The distance from the first bone-to-implant-contact to the implant shoulder as reference (yellow line) was measured.

Figure 2b. Standardized radiograph illustrating the measured distance from bone level to implant shoulder as reference (yellow arrows).

Figures 3-4. Two clinical cases illustrating the considerable variations of bone loss from baseline (implant loading) to the 1-year follow-up).

Figure 3a.

Bone level of implant 13 at baseline (implant loading)

Figure $3 b$.

Bone level of implant 13 at 1year of loading

Figure 3c.

Bone level of implant 23 at baseline (implant loading)

Figure 3d.

Bone level of implant 23 at 1year of loading

Figure 4a.

Bone level of implant 13 at baseline (implant loading)

Figure $4 b$.

Bone level of implant 13 at 1year of loading

Figure 4c.

Bone level of implant 23 at baseline (implant loading)

Figure 4d.

Bone level of implant 23 at 1year of loading

Figure 5. Mean peri-implant bone loss $(\mathrm{mm})$ from baseline to 1 year per implant $(\mathrm{n}=37)$. One implant was lost. Negative values represent bone gain ( $\mathrm{mm})$.

Figure 6a: 1-year follow-up of 2 maxillary ball anchors surrounded by healthy mucosa.

Figure 6b: Mucosa overgrowth around ball anchors at the 1-year follow-up. 
Table 1. Distribution of implants (n) according to type (Standard Plus/Standard), length and region.

\begin{tabular}{|c|c|c|c|c|c|c|c|c|c|c|c|c|c|c|}
\hline & \multicolumn{3}{|c|}{ IImplant type } & \multicolumn{4}{|c|}{ Implant length } & \multicolumn{7}{|c|}{ Implant region } \\
\hline & SP & $s$ & Total & $8 \mathrm{~mm}$ & $10 \mathrm{~mm}$ & $12 \mathrm{~mm}$ & Total & 12 & 13 & 14 & 22 & 23 & 24 & Total \\
\hline $\begin{array}{l}\text { Implants } \\
(n=38)\end{array}$ & 15 & 23 & 38 & 1 & 12 & 25 & 38 & 1 & 16 & 2 & 4 & 14 & 1 & 38 \\
\hline
\end{tabular}

Table 2. Peri-implant bone loss (mm) at 12 months (mean, standard deviation, median, interquartile range, range). One implant was lost until 12 months $(n=37)$.

\begin{tabular}{|ccccccc|}
\hline $\begin{array}{c}\text { Bone loss at } \\
\mathbf{1 2} \text { months }\end{array}$ & $\mathbf{n}$ & Mean $(\mathbf{m m})$ & SD $(\mathbf{m m})$ & Median $(\mathbf{m m})$ & IQR $(\mathbf{m m})$ & Range $(\mathbf{m m})$ \\
\hline & 37 & 0.7 & 1.1 & 0.48 & 0.56 & $-2.4-5.8$ \\
\hline
\end{tabular}

Table 3. Bone loss (mm) at 12 months split for implants with and without GBR (mean, standard deviation, median, range).

\begin{tabular}{|llcccc|}
\hline $\begin{array}{l}\text { Bone loss } \\
\text { at 12 } \\
\text { months }\end{array}$ & $\mathbf{n}$ & $\begin{array}{c}\text { Mean } \\
(\mathbf{m m})\end{array}$ & $\mathbf{S D}(\mathbf{m m})$ & $\begin{array}{c}\text { Median } \\
\mathbf{( m m )}\end{array}$ & $\begin{array}{c}\text { Range } \\
\mathbf{( m m})\end{array}$ \\
$\begin{array}{l}\text { Implants } \\
\text { with GBR }\end{array}$ & 4 & 0.9 & 0.7 & 0.8 & 0.1 to 1.8 \\
\hline $\begin{array}{l}\text { Implants } \\
\text { without } \\
\text { GBR }\end{array}$ & 33 & 0.7 & 1.1 & 0.4 & $-0-7$ to 2.8 \\
\hline
\end{tabular}


Table 4. Bone loss (mm) at 12 months split for patients being smokers and non-smokers (mean, standard deviation, median, range).

\begin{tabular}{|lccccc|}
\hline $\begin{array}{l}\text { Bone loss } \\
\text { at 12 } \\
\text { months }\end{array}$ & $\mathbf{n}$ & $\begin{array}{c}\text { Mean } \\
(\mathbf{m m})\end{array}$ & $\mathbf{S D}(\mathbf{m m})$ & $\begin{array}{c}\text { Median } \\
\mathbf{( m m )}\end{array}$ & $\begin{array}{c}\text { Range } \\
\mathbf{( m m})\end{array}$ \\
$\begin{array}{l}\text { Implants } \\
\text { smokers }\end{array}$ & 6 & 1 & 1.6 & 0.4 & 0.1 to 4.2 \\
\hline $\begin{array}{l}\text { Implants } \\
\text { non- } \\
\text { smokers }\end{array}$ & 13 & 0.5 & 0.8 & 0.5 & -0.7 to 2.8 \\
\hline
\end{tabular}

Table 5. Bone loss (mm) at 12 months for implants supporting overdentures with and without palatal coverage (mean, standard deviation, median, range).

\begin{tabular}{|lccccc|}
\hline \multicolumn{1}{|c}{$\begin{array}{c}\text { Bone loss at 12 } \\
\text { months }\end{array}$} & $\mathbf{n}$ & $\begin{array}{c}\text { Mean } \\
\mathbf{( m m )}\end{array}$ & $\mathbf{S D}(\mathbf{m m})$ & $\begin{array}{c}\text { Median } \\
\mathbf{( m m )}\end{array}$ & $\begin{array}{c}\text { Range } \\
\mathbf{( m m}\end{array}$ \\
$\begin{array}{l}\text { Overdentures with } \\
\text { palatal coverage }\end{array}$ & 4 & 0.1 & 0.6 & 0.3 & -0.7 to 0.7 \\
\hline $\begin{array}{l}\text { Overdentures } \\
\text { without palatal } \\
\text { coverage }\end{array}$ & 15 & 0.9 & 1.2 & 0.5 & -0.1 to 4.2 \\
\hline
\end{tabular}


Figure 1

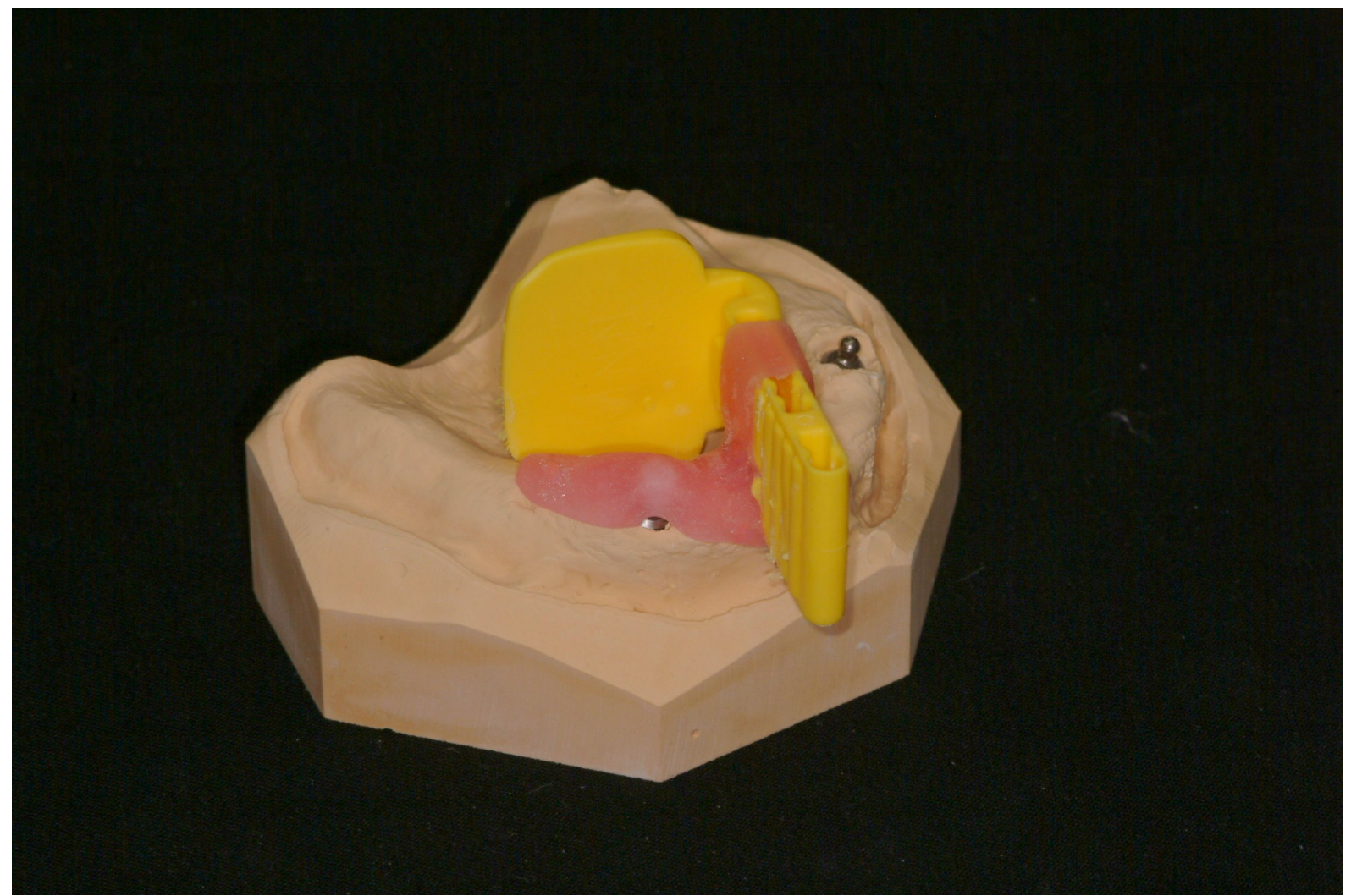

Figure $2 a$

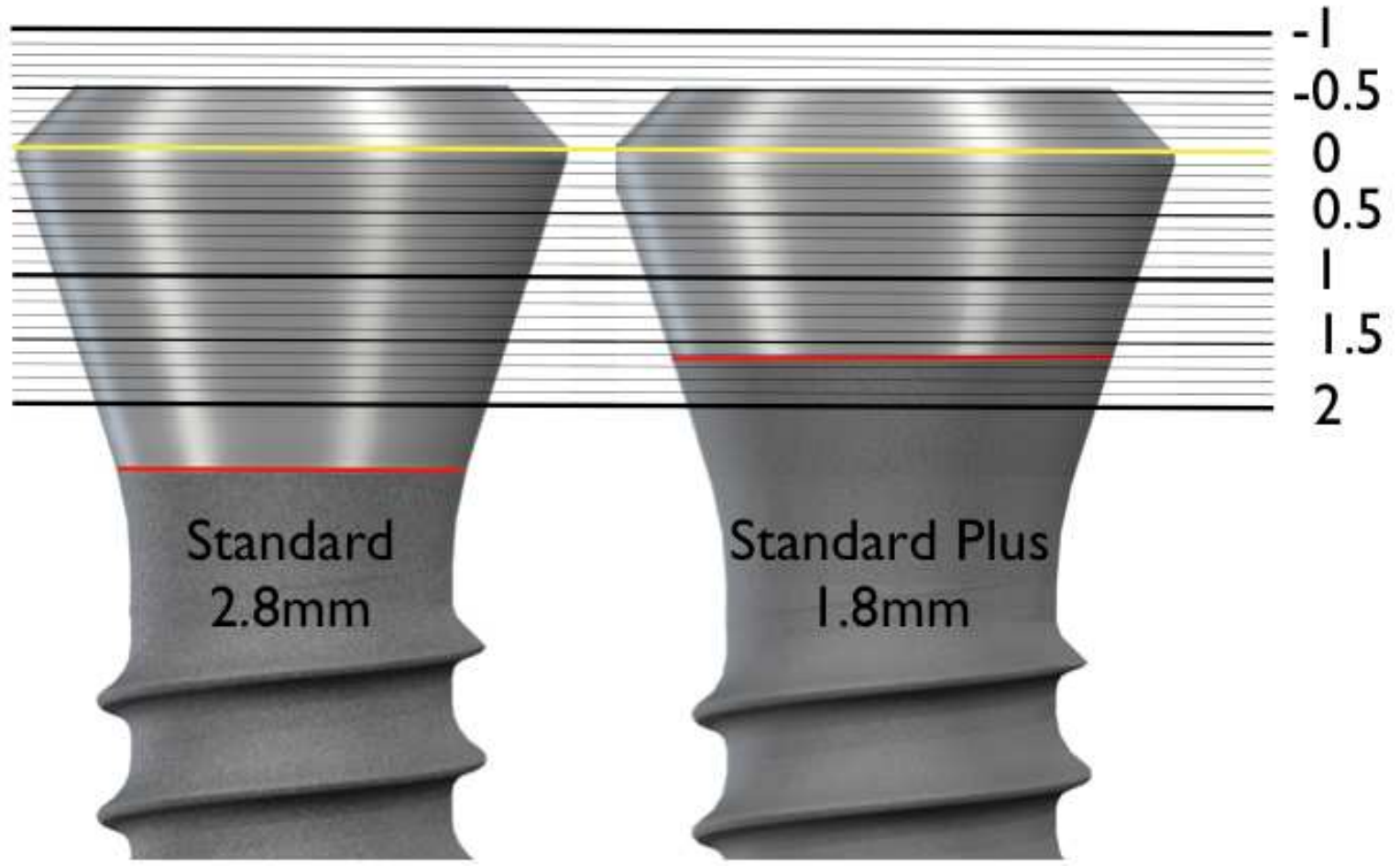


Figure $2 b$

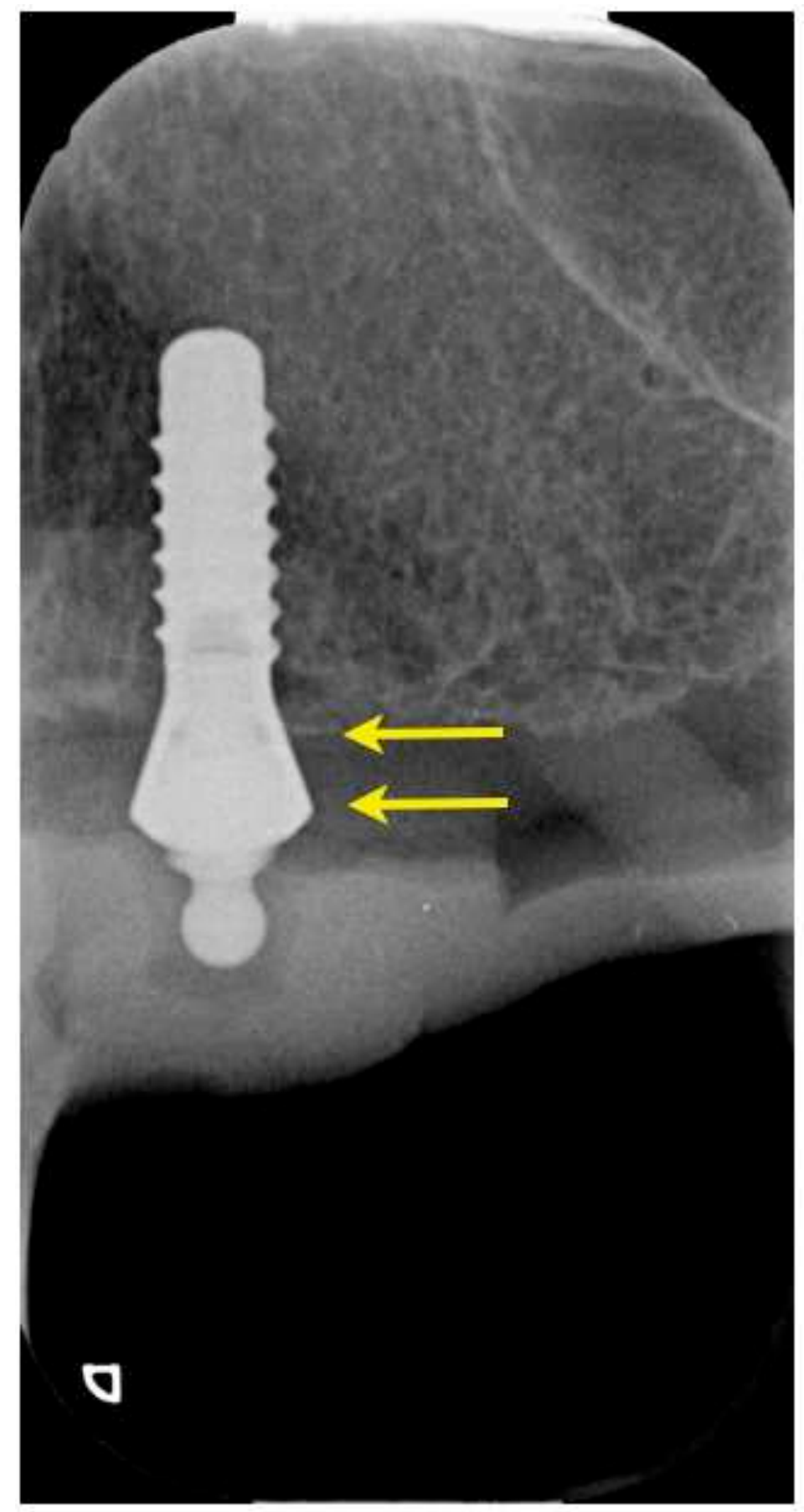


Figure $3 a$

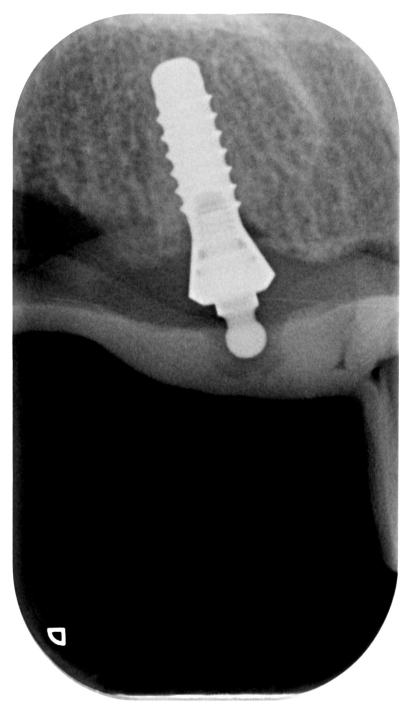

Figure $3 b$

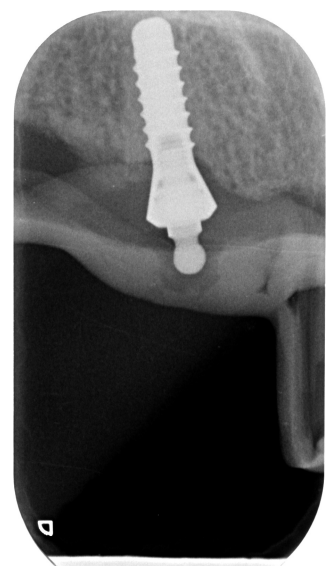

Figure 3c

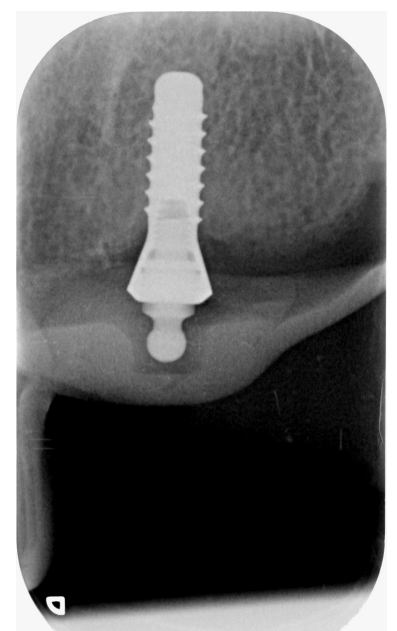


Figure 3d

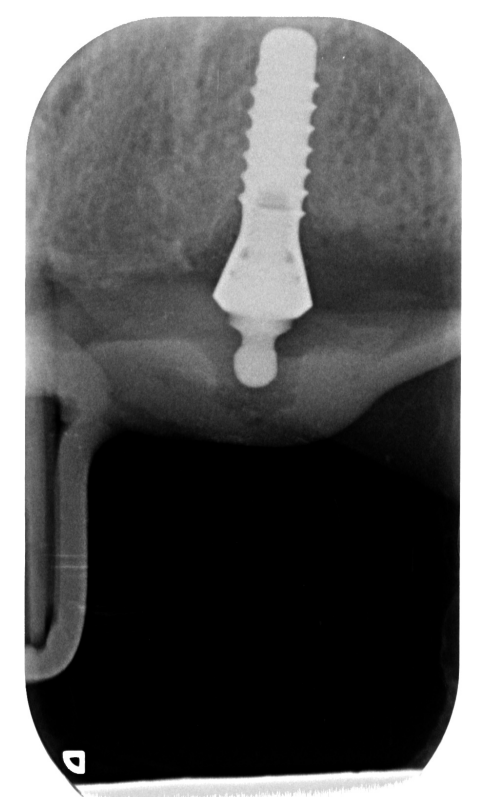

Figure 4a

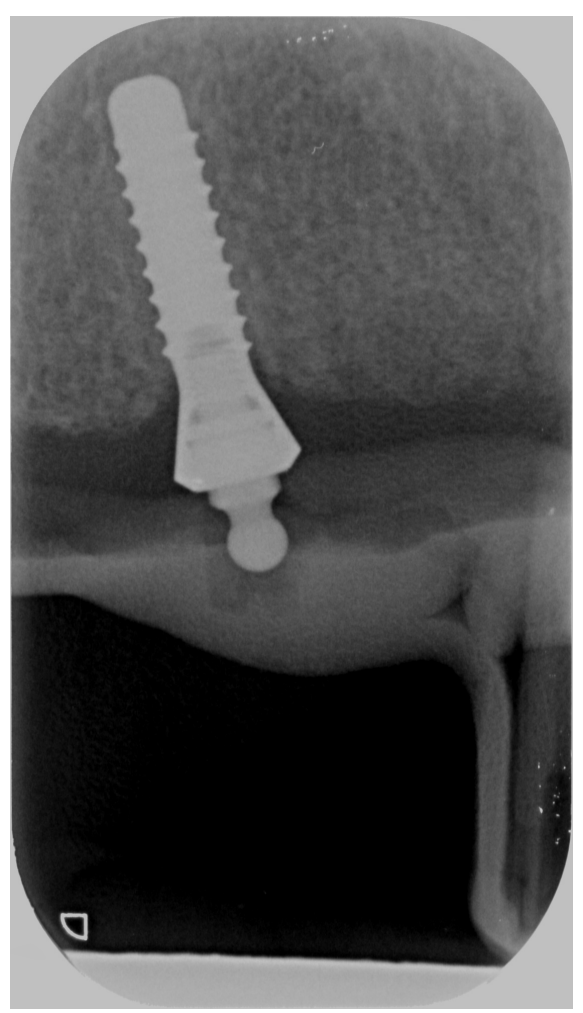


Figure $4 b$

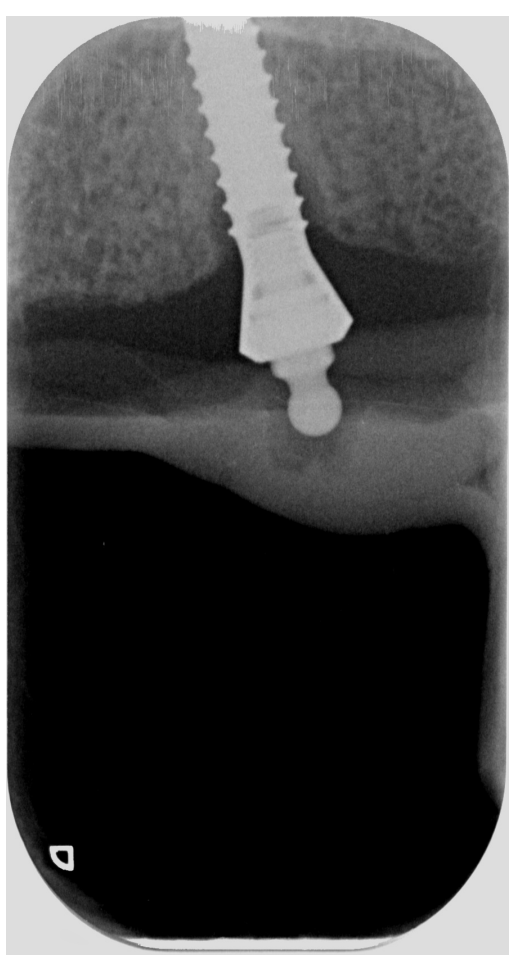

Figure 4c

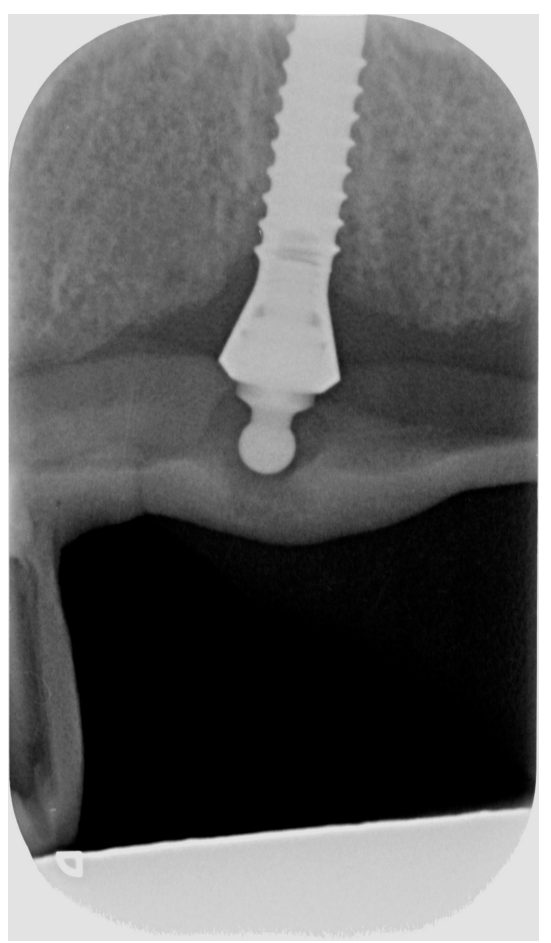


Figure 4d

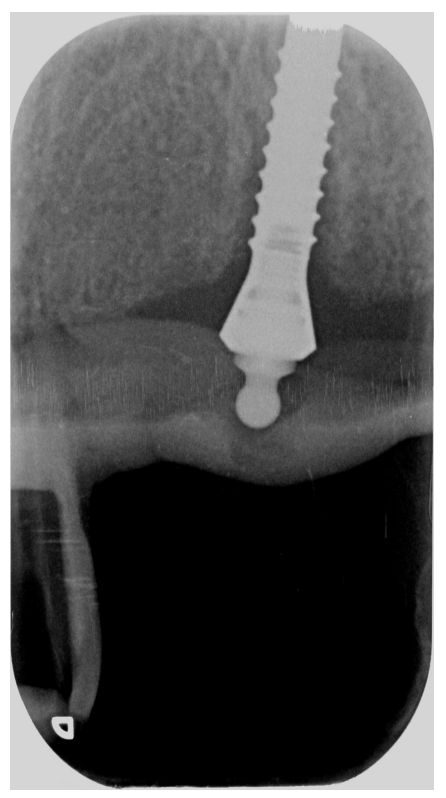

Figure 5

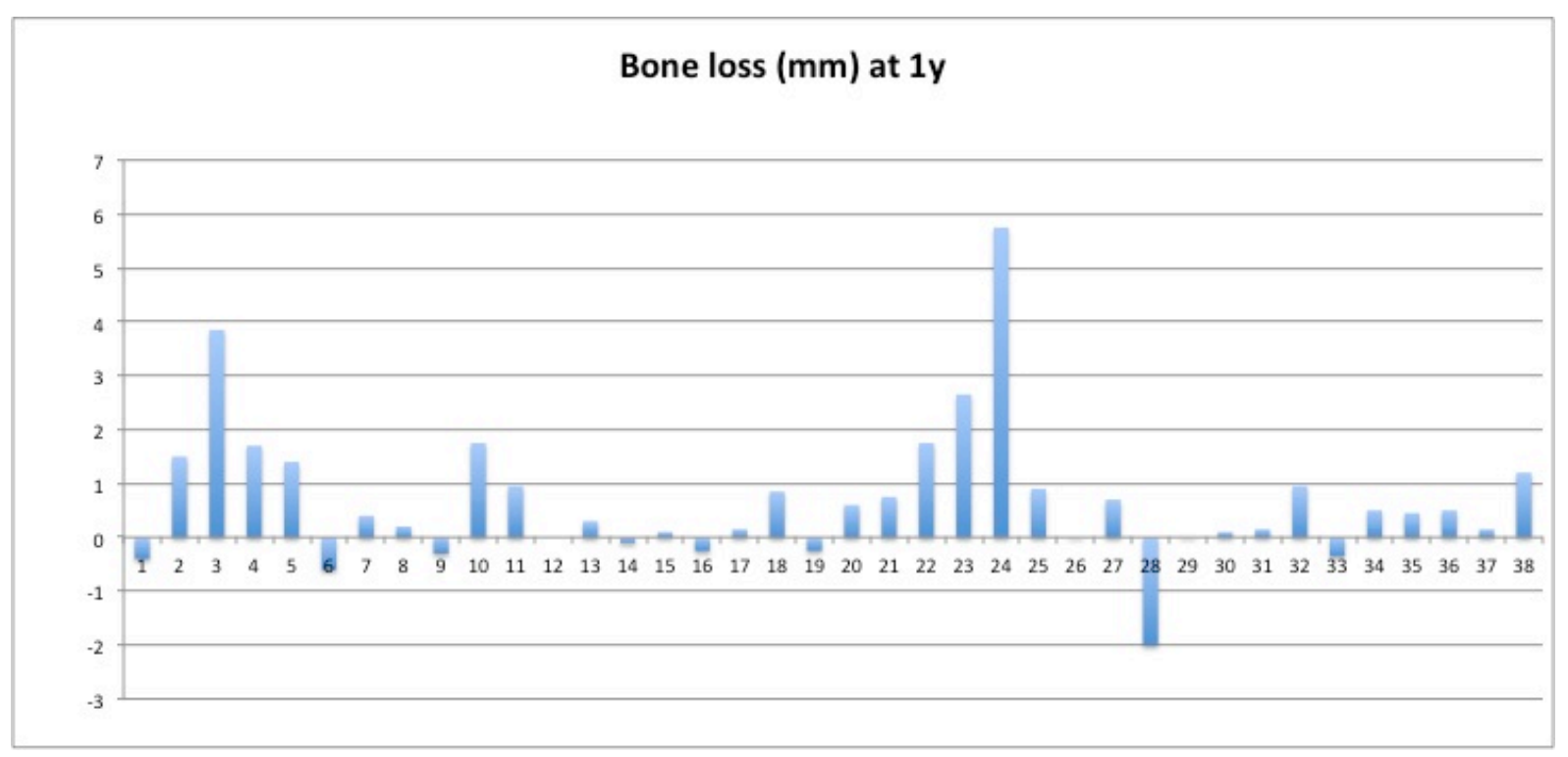


Figure 6a

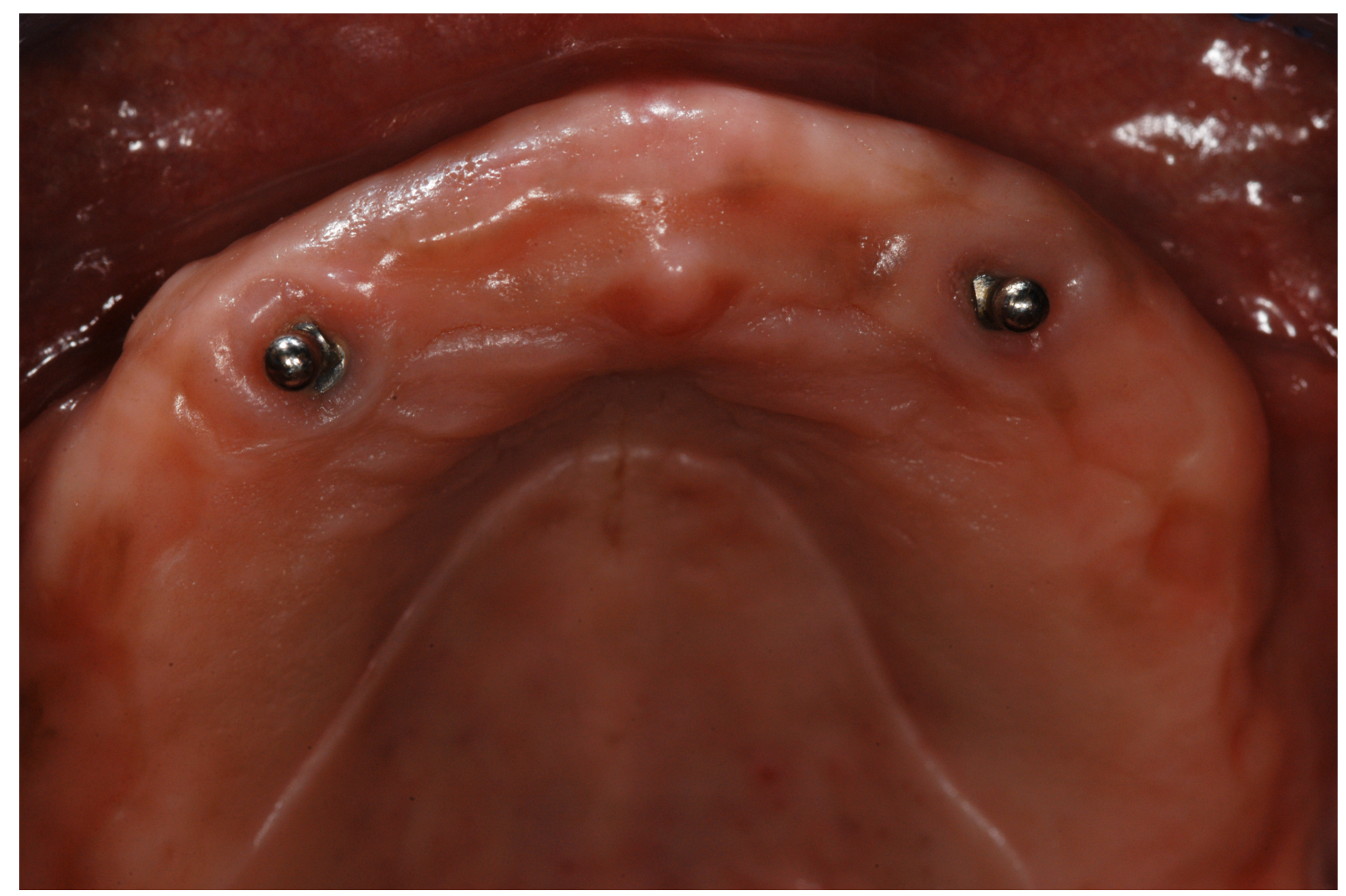

Figure $6 b$

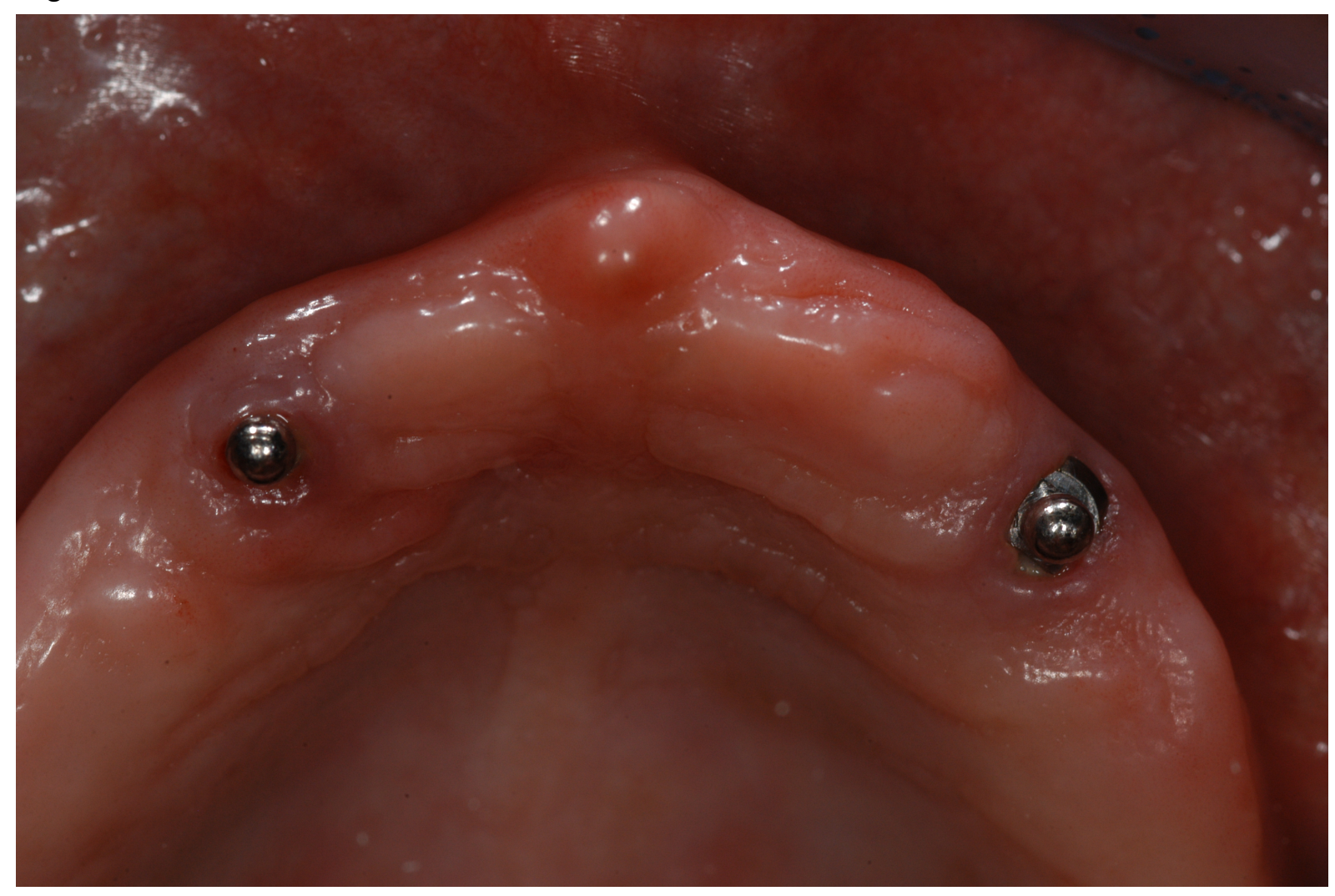

